\title{
The physiology of polar marine zooplankton*
}

\author{
ANDREW CLARKE and LLOYD S. PECK
}

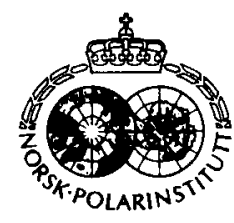

Clarke, A. \& Peck, L. S. 1991: The physiology of polar marine zooplankton. Pp. 355-369 in Sakshaug, E. Hopkins. C. C. E. \& Øritsland, N. A. (eds.): Proceedings of the Pro Mare Symposium on Polar Marine Ecology, Trondheim, 12-16 May 1990. Polar Research 10(2).

\begin{abstract}
The polar marine environment is characterised by low stable temperatures with seasonal variations ranging from $\pm 3^{\circ} \mathrm{C}$ at lower latitudes to only $\pm 0.2^{\circ} \mathrm{C}$ at high latitudes. The Arctic basin is dominated by multi-year ice. whereas the Antarctic is subject to large seasonal changes in the cover by annual sea ice. Primary production is intensely seasonal nearshore but probably less so in offshore waters where significant production is associated with the marginal ice zone. Oxygen consumption in polar zooplankton is low compared with temperate and tropical species. Annual growth rates are generally slow and, especially in herbivores, highly seasonal. It is likely that fast growth rates are possible for polar zooplankton in areas of high food availability such as ice-edge blooms, but these growth rates are not usually achieved in the more oligotrophic open-ocean areas. Lipid stores in polar herbivorous zooplankton are generally high, although some euphausiids and gelatinous zooplankton also rely on degrowth to provide energy over winter. Ice-edge blooms are of great importance to the polar marine food web although the quantitative significance of winter feeding under ice has yet to be resolved. Comparison of data on lipid storage and oxygen consumption for polar zooplankton indicates that there are large differences in the energy requirements of benthos and crustacean zooplankton. This is probably related to the high metabolic cost of staying in the water column. In contrast gelatinous zooplankton (salps, ctenophores, medusae and siphonophores) have a low energy throughput, related to a body composition which renders them essentially neutral in buoyancy and a slow but efficient means of locomotion. Under good feeding conditions many species can therefore grow and reproduce very rapidly. This emphasises the distinct energetic regime of gelatinous zooplankton, now known to be a group of major ecological importance in most waters of the world.
\end{abstract}

Andrew Clarke and Lloyd S. Peck, British Antarctic Survey, High Cross, Madingley Road, Cambridge CB3 OET, UK (revised January 1991).

\section{Introduction}

The cold waters of high latitudes have long interested physiologists because they represent one extreme of the range of conditions to which marine organisms have become adapted. Although it is natural from an anthropocentric viewpoint to assume that polar waters somehow represent a harsher environment than the apparently more equable waters of the tropics, this is not necessarily the case (Clarke \& Crame 1989).

A large amount of physiological and biochemical work has been undertaken on polar marine organisms and a complete review is beyond the scope of this paper. We have chosen instead to examine a number of related topics with the common theme of energy storage and utilisation. We shall contrast the Arctic and Antarctic where appropriate, using examples from both hemispheres, and attempt to highlight out-

\footnotetext{
* Keynote lecture presented at the Pro Mare Symposium on Polar Marine Ecology, Trondheim, Norway, 12-16 May 1990.
}

standing problems. First, however, it is necessary to outline the relevant features of high latitude marine environments and the organisms that live there.

\section{The polar marine environment}

Although the Arctic and the Antarctic marine systems are often treated together, they differ in many ways. Both are cold and covered by sea ice for much of the year, but they differ in extent, topography, oceanography and age. In both areas seawater temperatures are low and frequently reach $-1.9^{\circ} \mathrm{C}$. Seasonal variations in temperature are also small, although the amplitude is greater towards lower latitudes and is always more substantial in surface waters. A summer thermocline may develop but the generally stormy nature of these latitudes means that wind-induced mixing often extends to considerable depths. Some areas are both exceptionally cold and stable. At McMurdo Sound, Antarctica, the maximum annual temperature range is only $\pm 0.2^{\circ} \mathrm{C}$ either 
side of $-1.7^{\circ} \mathrm{C}$ (Littlepage 1965), making this one of the most thermally stable areas on earth.

Both the Southern Ocean and the Arctic basin are subject to sea ice but the nature of this ice differs in the two areas. In the Southern Ocean the ice is almost exclusively annual sea ice (pack ice). A synthesis of data from satellite imagery for 1973-1976 revealed a maximum cover of about $20 \times 10^{6} \mathrm{~km}^{2}$ in September and a minimum of about $3 \times 10^{6} \mathrm{~km}^{2}$ in February, although there were considerable year to year variations (Zwally et al. 1983). The Arctic differs in that the bulk of the sea ice is multi-year ice and even at the summer minimum $45 \%$ of the surface (roughly $6.5 \times 10^{6} \mathrm{~km}^{2}$ ) remains ice-covered. In winter this increases to about $12.5 \times 10^{6} \mathrm{~km}^{2}$ so the overall seasonality of the sea-ice cover is much less than in the Southern Ocean (Parkinson et al. 1987).

In both hemispheres the high latitude oceans show an intense seasonality of primary production. This is particularly marked in nearshore waters where summer chlorophyll standing stocks can exceed $50 \mathrm{mg} / \mathrm{m}^{3}$, although maxima of about $20 \mathrm{mg} / \mathrm{m}^{3}$ are more typical (Clarke et al. 1988; Holm-Hansen et al. 1989). The situation in the open ocean is more complex. Oceanic water blooms rarely reach the concentrations found closer inshore, and the distribution of phytoplankton biomass is patchy. In the Southern Ocean, open water blooms only occasionally develop to levels where nutrients are depleted, and peak standing crops of $1-4 \mathrm{mg} / \mathrm{m}^{3}$ are typical. The reasons for this are not fully understood, although the lack of water column stability because of the stormy conditions is generally accepted as the most likely explanation (Priddle et al. 1986). The role of grazing (both by macrozooplankton and microbial consumers) in limiting phytoplankton standing crop is still highly contentious (Smetacek et al. 1990).

Much higher standing crops, although still below those found in nearshore waters, are found associated with sea ice. However two aspects of sea-ice associated primary production are of importance to polar zooplankton. The first is the bloom associated with the water column stability induced by the receding ice front (Sullivan et al. 1988 ), the second is the possible role of under-ice grazing in supplying energy to zooplankton during the winter. The quantitative importance of this to adult zooplankton is still unclear but the significance to larval stages may be great (Daly \& Macaulay 1988; Marschall 1988; Ross et al. 1988).

\section{Polar zooplankton}

Organisms living in the sea vary in size from viruses to whales, a scaling range of more than nine orders of magnitude. For the purposes of this review, however, we will limit ourselves to the conventional macroplankton (invertebrate zooplankton greater than $1 \mathrm{~mm}$ in size). Although many taxa have been investigated by physiologists over the years, most work has concentrated on crustaceans, particularly copepods and euphausiids. We will therefore concentrate our discussion on these groups, touching on other organisms where relevant. Through the examination of data on growth rate, oxygen consumption, and energy storage, we attempt to distinguish the effects of temperature from those of seasonality, and we will conclude by contrasting the physiological ecology of zooplankton and benthos in an attempt to set these results in a (somewhat speculative) framework.

\section{Oxygen consumption}

Measuring the oxygen consumption of zooplankton presents a number of technical difficulties that are not always easy to overcome. These centre on the need to confine within a small space an organism adapted to an essentially limitless threedimensional environment. The major problems are controlling for handling stress and locomotor activity, but a variety of other influences render oxygen consumption one of the most difficult physiological variables to measure in a meaningful way (see discussion in Childress 1977).

It is usual for marine physiologists to separate the costs of locomotor activity (active metabolism) from those of maintenance (basal, resting or standard metabolism). Routine metabolism (the oxygen consumption of an organism at an activity level representative of normal existence) falls somewhere between these two extremes. Routine metabolism for a benthic invertebrate or demersal fish thus includes the costs of foraging, searching for mates, vigilance and so on. For a pelagic organism which must expend energy to remain in the water column, these distinctions are less helpful. It could be argued, for example, that some fractions of the costs of locomotor activity should be included in basal metabolism, for without this activity the organisms would drop out of the water column and die. 
In polar species these difficulties of definition may be compounded by an overall low rate of oxygen utilisation. In practical terms all these various difficulties together mean that different measurements on the same animal can give somewhat different results. Clearly, even when the influence of the experimenter has been minimised there is no such thing as a definitive respiration rate for any marine invertebrate.

Nevertheless there is a need for some form of representative value to use in energetic calculations, or for comparison with other species. The major problem here is the influence of locomotor activity on oxygen consumption, for direct measurements of activity costs in large crustaceans have suggested that these costs are substantial (Torres et al. 1982; Torres \& Childress 1983). Since few reports of the oxygen consumption of marine zooplankton give any information on activity, the only practical approach with presently available studies is simply to accept the data we have and look for broad trends. One of the comparative aspects of respiratory physiology that has attracted much attention has been the relationship between respiration rate and temperature.

There are two important aspects to this relationship. The first is the effect of acute tem- perature change on metabolic rate, the second is the nature and extent of evolutionary adaptation to temperature. In general, following an acute rise in temperature, metabolic rate increases essentially in respone to thermodynamic constraints. This acute effect may be modulated by periods of acclimation prior to making any measurement. Although there have been a few indications of unusually high temperature sensitivity in polar marine zooplankton (that is, high $Q_{10}$ values), these have generally not been substantiated when studies are confined within a reasonable temperature span, when $Q_{10}$ values are usually within the normal biological range of 1 to 4 .

Of wider interest is the rate of oxygen consumption of polar zooplankton in relation to species from lower latitudes. This topic has been reviewed recently (Clarke 1991) and so will only be outlined here. Several authors have pooled data from many studies and looked for temperature (and hence latitudinal) trends. The results are summarised in Fig. 1. Although the individual relationships differ in temperature sensitivity (Table 1), the overall pattern is clear: polar marine invertebrates have a lower oxygen consumption than species from warmer waters. There is no evidence that the costs of growth or

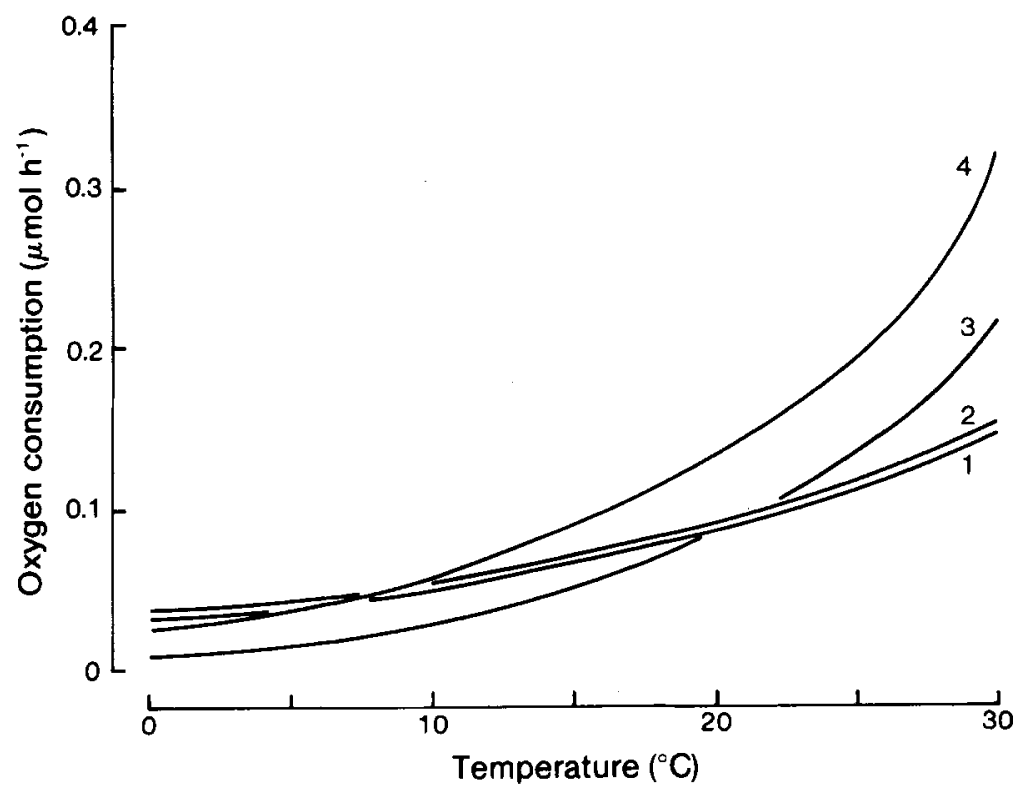

Fig. 1 . The relationship between respiration rate and temperature in different groups of marine organisms. $1=$ zooplankton (Ikeda 1974). 2 = zooplankton (Ikeda 1985). 3 = crustaceans (Ivleva 1980). 4 = non-idotheid isopods (Luxmoore 1984). From Clarke (1991). 
Table 1. Temperature and respiration in marine invertebrates (from Clarke 1991).

\begin{tabular}{lccc}
\hline Group & $\mathrm{Q}_{1+1}$ & $\begin{array}{l}\text { Rangc }\left({ }^{\circ} \mathrm{C} \text { ) over }\right. \\
\text { which } \mathrm{Q}_{(1)} \text { calculated }\end{array}$ & Reference \\
\hline Zooplankton & 1.76 & 4.5 to 28.5 & Ikeda 1970 \\
Zooplankton & 1.63 & -1.4 to 30 & Ikeda 1985 \\
Crustaceans & 2.27 & 0 to 30 & Ivleva 1980 \\
Isopods & 2.98 & -1.5 to 25 & Luxmoore 1984 \\
Gastropods & 2.13 & -1.7 to 30 & Houlihan \& Allan 1982 \\
\hline
\end{tabular}

locomotor activity vary with temperature (although the effect of viscosity, which itself varies with temperature, on the cost of locomotion should not be ignored). The most likely explanation of the shape of these curves is thus a variation in the cost of basal (maintenance) metabolism with temperature (Clarke 1983. 1987a, 1991). Precisely what physiological processes constitute basal metabolism is not clear, but current data suggest that major components are protein turnover, cardiovascular, and osmotic work. It would clearly be of value to see how the rate of these processes varies with latitude.

Possible correlates of these reduced metabolic costs at low temperature include a reduced annual energy requirement, an increased ecological growth efficiency (Clarke 1987b), and a reduced requirement for an overwintering energy store.

\section{Growth rate}

It has been known from the earliest studies of polar organisms that high latitude marine invertebrates tend to grow slowly compared with those from lower, warmer water latitudes (Clarke 1983, 1988; Siegel 1987). A corollary of these slow overall growth rates is that lifetimes are often long and reproductive maturity is often delayed.

Why do polar marine invertebrates grow slowly? The initial, intuitively appealing explanation was that the processes of growth were simply slowed by the low temperatures. This hypothesis was later superseded by a more complex explanation involving a relatively high basal metabolism at low temperatures resulting in proportionately less energy being available for growth (so-called metabolic cold adaptation). Neither of these explanations now appears to be correct. There is an enormous volume of literature showing clearly how within a given species of fish or aquatic invertebrate growth can be reduced by lowering the temperature and increased by increasing the ration levels (see Cushing 1975 for a series of examples for fish). These results are often mistakenly extrapolated to the polar environment and used to explain the slow growth of polar marine organisms simply on the grounds that the water is cold. This however seems unlikely given the extensive (though not always perfect) compensation for temperature which has been achieved in many physiological processes (see Clarke 1991 for a review). Metabolic cold adaptation is also unlikely to provide an explanation for slow growth since the low resting oxygen consumption of polar marine invertebrates (Fig. 1) would rather suggest that more, not less, energy is available for growth.

One of us recently proposed that slow growth is caused principally by seasonal resource limitation (Clarke 1988). This hypothesis is difficult to test, for if an animal is shown to be growing slowly it is often impossible to tell whether growth is being limited by temperature or food (for a more detailed explanation of this point see Clarke 1991; Clarke \& North 1991). The difficulty here is to decide whether polar marine organisms have been able to evolve compensation for temperature in the growth process; in other words, how fast can they grow when food is available? Fortunately the seasonal nature of the polar marine enviroment allows us to examine this point. If growth in polar species is limited by food rather than temperature. we can make the following two predictions:

1. Growth will be seasonal in herbivores, and less seasonal in carnivores (reflecting the differing patterns of seasonal abundance in their food).

2. Growth rates of polar species in the presence of excess food will be comparable with those of related temperate or tropical species under similar conditions.

The second prediction is difficult to test, for non- 
limiting food is a most unusual ecological situation in the sea, and many other constraints or confounding factors may intervene. It may be possible to test this prediction experimentally with larval or juvenile stages fed ad lib. in the laboratory (Clarke \& North 1991). A more practical approach however would be to test a third prediction:

3. Maximum growth rates will be comparable with those of similar or related species from warmer waters.

\section{Seasonal growth}

Strongly seasonal growth is shown by many species of polar euphausiid including Meganyctiphanes norvegica (Båmstedt 1976; Falk-Petersen 1981), Thysanoessa inermis, T. raschii (Falk-Petersen 1981), Euphausia superba and to a lesser extent E. triacantha (Baker 1959; Siegel 1987). More rapid growth in summer has also been reported in the mysid Antarctomysis maxima (Ward 1984), the salp Salpa thompsoni (Foxton 1966) and the amphipod Themisto gaudichaudii (Kane 1966).

Many polar copepods overwinter as late copepodite stages (frequently CIV or CV), with maturation, egg production, and the early copepodite stages being confined to summer. Representative examples are Calanus glacialis from the Arctic (Tande et al. 1985) and Calonoides acutus from the Antarctic (Andrews 1966). Voronina et al. (1980a) have modelled the seasonal pattern of growth in Calanoides acutus, showing how production is limited essentially to just five months of the year. Although the life cycle model on which this analysis was based is somewhat simplified, the results demonstrate very clearly the intensely seasonal production typical of high latitude herbivorous zooplankton. Some carnivorous species (for example Euchaeta spp.) produce eggs during winter, but this is at the expense of previously stored lipid reserves (Clarke 1983).

Species without strongly seasonal growth tend to be carnivorous; a good example is the chaetognath Sagitta gazellae (David 1955). Chaetognaths follow the seasonal migration of their copepod prey and their impact on the overwintering copepod population can be substantial (Øresland 1990).

Overall these observations are precisely what would be expected from a food-limited system, with obligate herbivores having growth (and in many cases reproduction) tightly coupled to the summer phytoplankton bloom, and carnivores often (but not always) decoupled.

\section{Maximal growth rate}

The seasonal growth of many species suggests that at the height of the production season instananeous growth rates may be quite high. Unfortunately the nature of much biological oceanographic research makes this difficult to test. Samples are usually taken only over a short time period in any one body of water and so a more general picture over a longer time span can be obtained only by combining many data sets. As a result, spatial and temporal detail is blurred by sampling error, geographical variation, and year to year differences.

This point is neither new nor original, but it is germane to an understanding of data on zooplankton growth rates. It emphasises that the only way to obtain unequivocal growth rate data for a population is to obtain frequently spaced sequential samples from a single population. This is not a simple task in the open ocean, and so it is not surprising that one of the best examples comes from the study of the major zooplankton in Balsfjorden, northern Norway. Samples were taken monthly and the growth and biochemical composition of three euphausiids and two copepod species were followed throughout their lifecycles (Falk-Petersen 1981; Hopkins et al. 1984).

In O-group Thysanoessa inermis there was no growth over winter but growth was extremely rapid once the phytoplankton bloom got underway. Dry mass peaked in September and then declined significantly (degrowth) over winter, followed by further growth in the subsequent summer. A similar picture was found for the sympatric $T$. raschii (Fig. 2). The herbivorous copepod Calanus finmarchicus reached asymptotic wet mass within two months of spawning, and the carnivorous Metridia longa within three months (Hopkins et al. 1984).

These results indicate that instantaneous growth rates of polar zooplankton can be quite high. Most data from oceanic populations, however, suggest slower growth rates. Antarctic euphausiids and mysids frequently show slow growth overall, and the fastest summer rates are not as rapid as those reported from Balsfjorden (Ward 1984; Siegel 1987). 


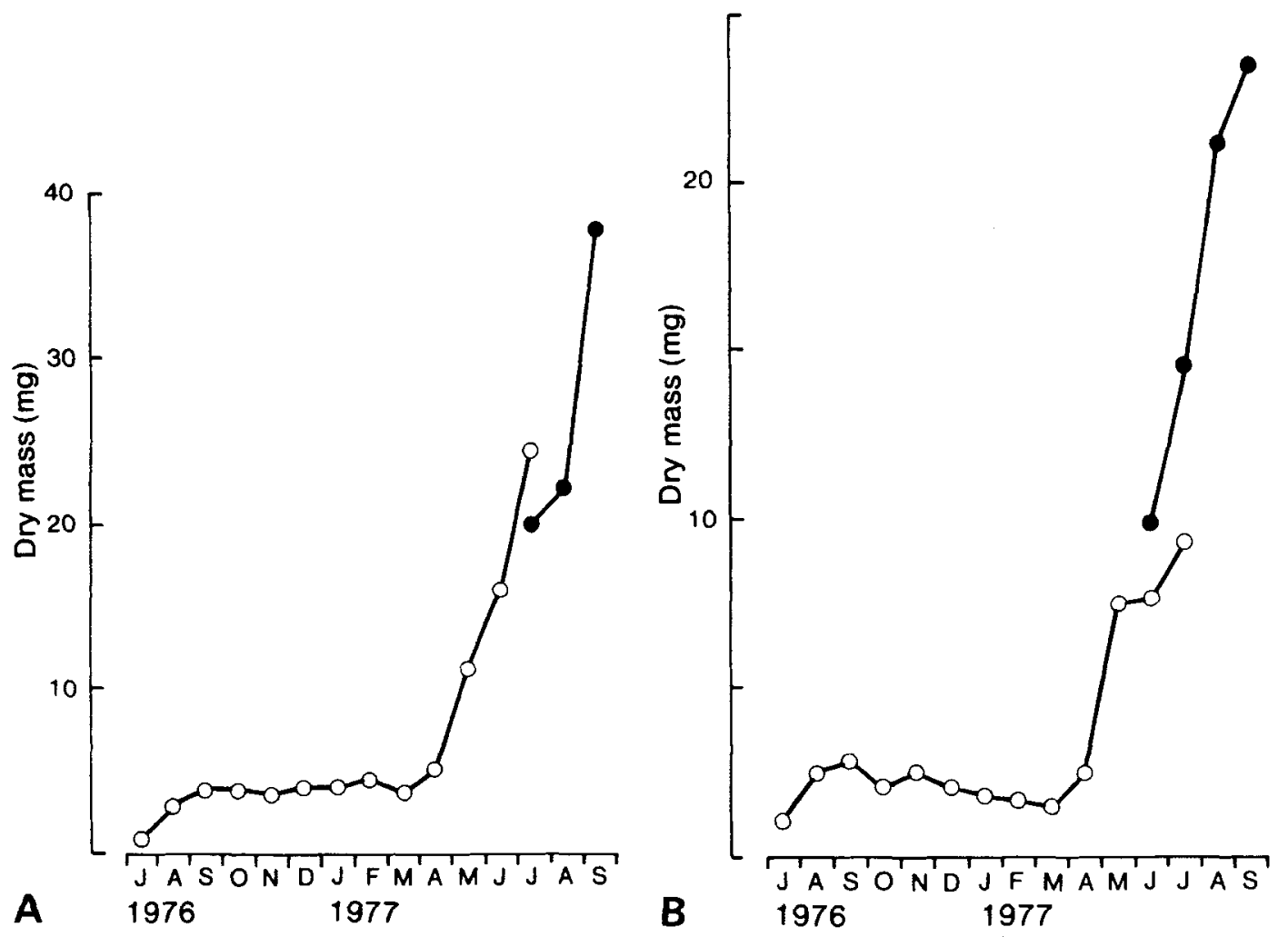

Fig. 2. Growth (dry mass. $\mathrm{mg}$ ) in two euphausiids from Balsfjorden, northern Norway. A. Thysanoessa inermis. B. Thysanoessa raschii. Redrawn from Falk-Petersen (1981). The two symbols indicate different year-classes sampled at the same time; the graphs thus do not represent continuous growth by a single cohort. The vertical scalc means that winter degrowth is not clearly visible.

A more varied picture is presented by studies of oceanic copepods. For example in Calanoides acutus from the southern Drake Passage the rate of development for early copepodite stages is about one month per stage (Huntley \& Escritor 1991). A similar growth rate has been reported from Ezcurra Inlet, King George Island (Chojnacki \& Weglenska 1984). Other recent studies from slightly warmer waters further north have indicated, however, that faster rates are quite possible. Data for Calanoides acutus obtained by Andrews (1966) during the Discovery Investigations indicate that passage through the early copepodite stages ( $\mathrm{Cl}$ to $\mathrm{CIII}$ ) may take place within a single month (Atkinson 1989). This is supported by samples taken by RRS William Scoresby and RRS Discovery II in 1928-1951 from the Southern Ocean, and also the population structure proposed by Voronina et al. (1978), which indicates that passage through the early copepodite stages of Calanoides acutus and $\mathrm{Cal}$ anus simillimus may be achieved within only four to six weeks (Atkinson 1991). Growth rates of several copepod species around South Georgia also appear to be high, although the data here is not conclusive (Atkinson 1989).

We cannot conclude from these analyses that all polar zooplankton are capable of rapid growth under the right circumstances, but the evidence is suggestive. Two points are worth making in this context. The first is that the ability to grow fast in polar waters would indicate a substantial (but not necessarily perfect) degree of temperature compensation in growth rate. This has been suggested for Calanus finmarchicus (Matthews 1968) and also in populations of estuarine harpacticoid 
copepods along a latitudinal cline alone the eastern seaboard of the United States (Lonsdale \& Levinton 1986).

The second point is that growth rate would be expected to vary from place to place, and from year to year, because of differences in food availability. Copepod egg production has long been known to respond to food level both in the field (Gatten et al. 1980) and in the laboratory (Hirche $1989,1990)$. Demonstrating a response in growth rate is more difficult, but this has recently been shown clearly for seven species of cladoceran by Gliwicz (1990), and has long been known for fish (see Cushing 1975 for an excellent series of examples).

Overall we must conclude that although there is some evidence that polar zooplankton can achieve fast growth rates in some areas, we cannot confirm that these rates are fully comparable with those in species from warmer waters. If food availability is the primary driving force in determining field growth rates in polar zooplankton, this would explain why open-ocean growth rates are generally slower than those in animals associated with ice-edge blooms, and why production cycles tend to track the retreat of the ice edge (Vorinina et al. 1980). In the more oligotrophic open-ocean areas it is probable that the potential for fast growth present in polar marine zooplankton is simply not realised. Similar considerations apply to carnivorous species such as pteropods, chaetognaths, amphipods, and gelatinous species which prey on the herbivores feeding on the iceedge bloom. We urgently need of more physiological measurements from zooplankton sampled during the production season at the ice-edge.

\section{Energetics during winter}

The intense seasonality of primary production in the polar oceans means that food for herbivorous zooplankton is severely limited in winter. Many species thus enter a non-feeding mode and overwinter at depth, utilising lipid reserves synthesised the previous summer. These reserves may be used to fuel both maintenance metabolism and the production of eggs to be spawned at the beginning of the next bloom.

The lipid reserves of polar zooplankton have been reviewed on several occasions (Clarke 1983, 1984a; Båmstedt 1986; Hagen 1988), and so a further review will not be attemped here. Following are the major points that have emerged over the past $15-20$ years:

1. Polar copepods (summarised by Båmstedt 1986) and euphausiids (Falk-Petersen 1981) tend to synthesise larger lipid stores than species from warmer waters at lower latitudes (Fig. 3). This is because the effect of the increased seasonality of food availability for herbivores at high latitudes outweighs the benefits to be gained from a reduced maintenance metabolism (Fig. 1) and hence necessitates a greater overwintering energy reserve.

2. Lipid stores tend to be wax ester (WE), especially in copepods, although triacylglycerol (TAG) is frequent and alkyldiacylglycerol also found in some species (Clarke, 1984a; Hagen 1988). It is noteworthy that the polar freshwater copepod Pseudoboekella poppei stores TAG rather than WE (Clarke et al. 1989), and this may be general for freshwater zooplankton (Morris 1983, 1984).

3. Carnivorous zooplankton tend to synthesise smaller lipid reserves than herbivorous species, though exceptions do occur (for example carnivorous copepods and amphipods can both be rich in lipids). The function of the lipid stores in chaetognaths and some gelatinous zooplankton is unknown. They may serve as energy reserves, an aid to buoyancy, or may represent a way of sequestering excess lipid from the diet (Clarke 1984a; Hagen 1988; Larson \& Harbison 1989).

4. Benthic species tend to have low lipid contents. Although in many species maturation of the ovary increases the lipid content, the latter never reaches the levels found in zooplankton (Clarke 1983, 1984b).

Most measurements of zooplankton lipid reserves have been spot measurements. There have been few seasonal studies although these are necessary for elucidating the role of lipid reserves. Important studies are those of Littlepage (1964) on Euphausia crystallorophias and Euchaeta antarctica at McMurdo, and Falk-Petersen (1981) on euphausiids in Balsfjorden, northern Norway.

Although utilisation of lipid reserves is the most obvious mechanism used to supply energy over winter in polar zooplankton, some euphausiids appear to utilise body protein. This results in a loss of mass (degrowth) during winter. Degrowth 


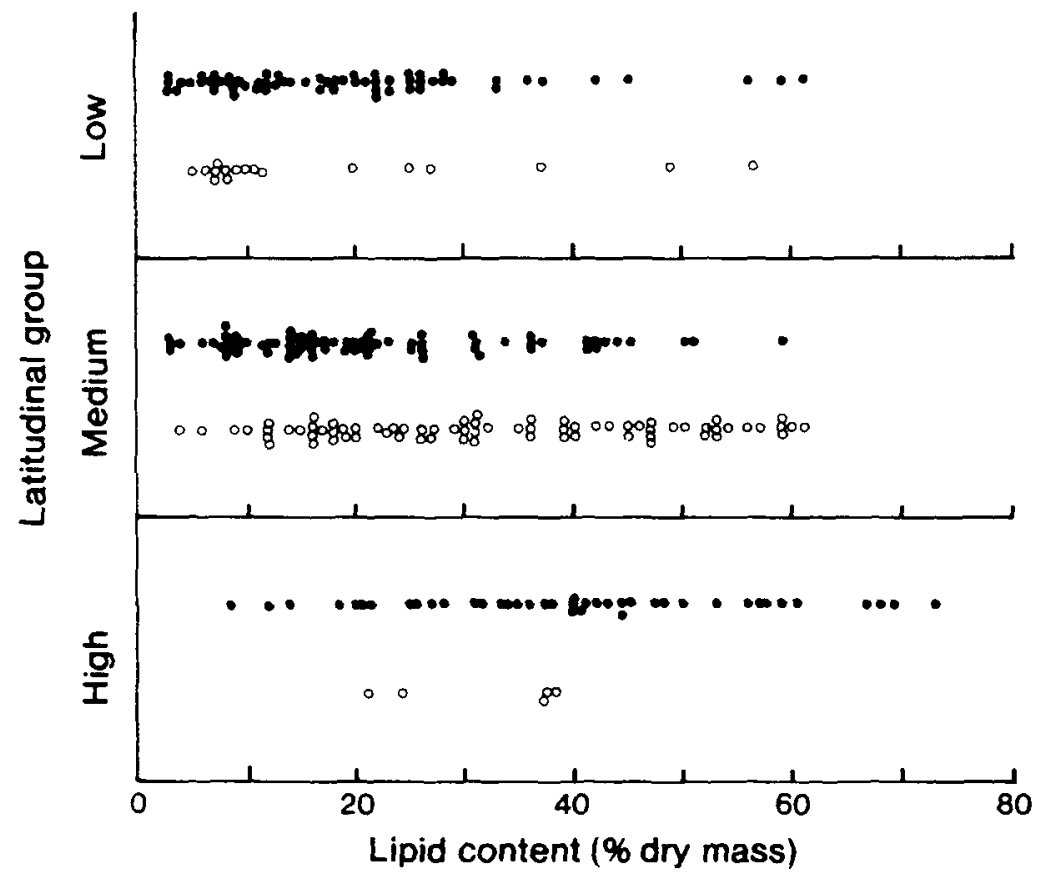

Fig. 3. The lipid content (\% dry mass) of copepods from high (polar), intermediate and low latitudes. Species have also been subdivided into shallow (O) and deep (O) water forms. Redrawn from Bàmstedt (1986), itself based on Clarke (1983) and the initial diagram of Lee \& Hirota (1973).

has been clearly demonstrated in several Arctic species (Falk-Petersen 1981; Båmstedt 1976) and in the laboratory for Euphausia superba (Ikeda \& Dixon 1982). Whether degrowth occurs in the wild in the latter species is unclear, although Ettershank's analysis (1983) of samples taken in winter by Stepnik at Arctowski station, King George Island, strongly suggests that it does.

\section{The role of sea ice}

The potential importance of sea ice to the ecology of polar zooplankton has long been recognised. However it is only in the last ten years that the complexity of this interaction has been realised (Carey 1985). It is not within the remit of this paper to review the interaction of zooplankton and sea ice. but several points are germane to polar zooplankton physiology:

1. It is likely that ice-associated blooms represent the best feeding conditions encountered by open-ocean (as distinct from nearshore) polar zooplankton. The fastest growth rates and/or largest reproductive output will therefore be found in these areas. This will apply alike to herbivorous species and the predators (both invertebrate and fish) that consume them. The precise quantitative importance of ice-associated biological activity in the overall pattern of carbon and energy flow in polar oceans has yet to be established, but current evidence suggests it is substantial.

2. Sea ice may contain a significant biomass of microbial organisms at, or close to, its lower (sea water) interface. This is used as a source of food by a range of zooplankton including copepods, amphipods, and euphausiids; predatory organisms such as ctenophores have been noted feeding on these herbivores. Again the precise quantitative importance of this system is unknown, although it has been proposed that ice algae may be of vital significance to the over winter survival of larval and immature Euphausia superba (Daly \& Macaulay 1988; Marschall 1988; Ross et al. 1988). 


\section{A comparison of the energetics of plankton and benthos}

In this final section we will attempt a broad-brush picture of the energetic differences between living in the water column and living on the sea bed. This will inevitably be somewhat speculative, but we believe that the intense seasonality at high latitudes accentuates this contrast, highlighting patterns which although present at lower latitudes may not be so clear there. We shall examine in turn lipid storage, oxygen consumption, and total energy flux.

\section{Lipid storage}

We have already highlighted the tendency for polar zooplankton to have larger lipid reserves than related species from lower latitudes (Fig. 3). In Fig. 4 we have plotted all the lipid data for polar marine invertebrates known to us, with data for plankton and benthos grouped separately. Because of possible differences in the pattern of food availability, we have also separated each category into herbivores and omnivores/ carnivores, making a total of four basic categories.

In general those polar benthic herbivores that have so far been examined have low lipid contents. The lipid contents of benthic carnivores are somewhat higher, but still lower, than planktonic herbivores. Pelagic invertebrates show a range of lipid contents and composition. These vary from the low amounts of lipid dominated by triacylglycerol in gelatinous species, chaetognaths, and the predatory annelid Vanadis antarctica, through intermediate levels (amphipods) to the very high lipid contents dominated by wax ester typical of calanoid and euchaetid copepods. Part of this variability is undoubtedly associated with size and developmental stage. Smaller species tend to have higher percentage lipid contents and this may be due in part to mass-specific metabolism being higher in smaller organisms.

A similar difference in tissue energy concentration between benthos and plankton in Kosterfjord, Sweden, was demonstrated by Norrbin \& Båmstedt (1984). They found that when organisms were classified according to tissue energy content (expressed as cal/mg AFDM), there was almost complete separation of benthic

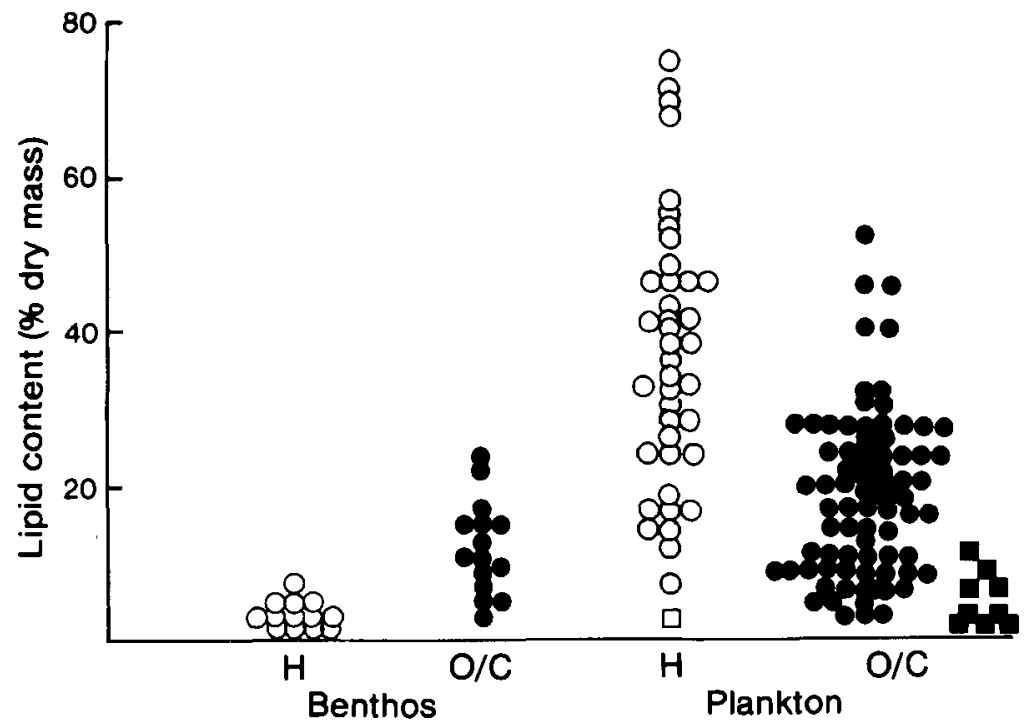

Fig. 4. Lipid contents (\% dry mass) for high latitude benthic and pelagic marine organisms. Open symbols denote herbivores and closed symbols carnivores/omnivores. The data for gelatinous zooplankton are shown as squares. The data are from Ikeda (1972), Lee (1974, 1975). Clarke (1977, 1984a, b), Percy (1979), Bămstedt (1980, 1986). Percy \& Fife (1981), Sargent \& Falk-Petersen (1981), Lawrence \& Guille (1982), Falk-Petersen ct al. (1982), and Larson \& Harbison (1989). Note that many data points overlap. Modified from an unpublished manuscript by Peck \& Clarke. 
and planktonic species. The planktonic species had the more energy-rich tissue, and Norrbin \& Båmstedt suggested this was due to the high lipid contents of many planktonic marine organisms. Low energy contents were also found in 121 species of Arctic benthic invertebrate by Wacasey \& Atkinson (1987). These suggestions are confirmed by the data summarised in Fig. 4.

\section{Oxygen consumption}

In Fig. 5 we have undertaken a similar analysis on all the measurements of the oxygen consumption of polar marine invertebrates known to us. A major difficulty with this type of comparative study is allowing for the (sometimes very large) differences in size of the various organisms. For each species an absolute oxygen consumption was calculated from published data, for the middle of the size range over which measurements were made. Where the original data were presented in volume terms, these were converted to molar units assuming STP. The absolute rate was then divided by the dry mass of the animal to produce a representative mass-specific rate of oxygen consumption. This does not remove the effects of size, for in most organisms mass-specific metabolic rate itself varies with size. However, the effect is relatively small.

A comparison of the metabolic rates of the four species groups in Fig. 5 indicates that a clear distinction can be drawn between benthic and planktonic species. On average, the metabolic rate of a typical planktonic species exceeds that of a typical benthic species by a factor of about $\times 6$. Since polar metabolic rates in general are low (Fig. 1), this emphasises that the metabolic rates of many polar benthic species are generally very low indeed (see, for example, Peck et al. 1986). This factor is, of course, an average value; it is clear from Fig. 5 that comparative studies of selected benthic and planktonic forms might reveal factors either much larger or smaller than $\times 6$.

Some of the variation in Fig. 5 will be related to differences in size. However the allometric exponent for mass-specific metabolic rate (generally of the order of $0.2-0.3$ ) is too small to

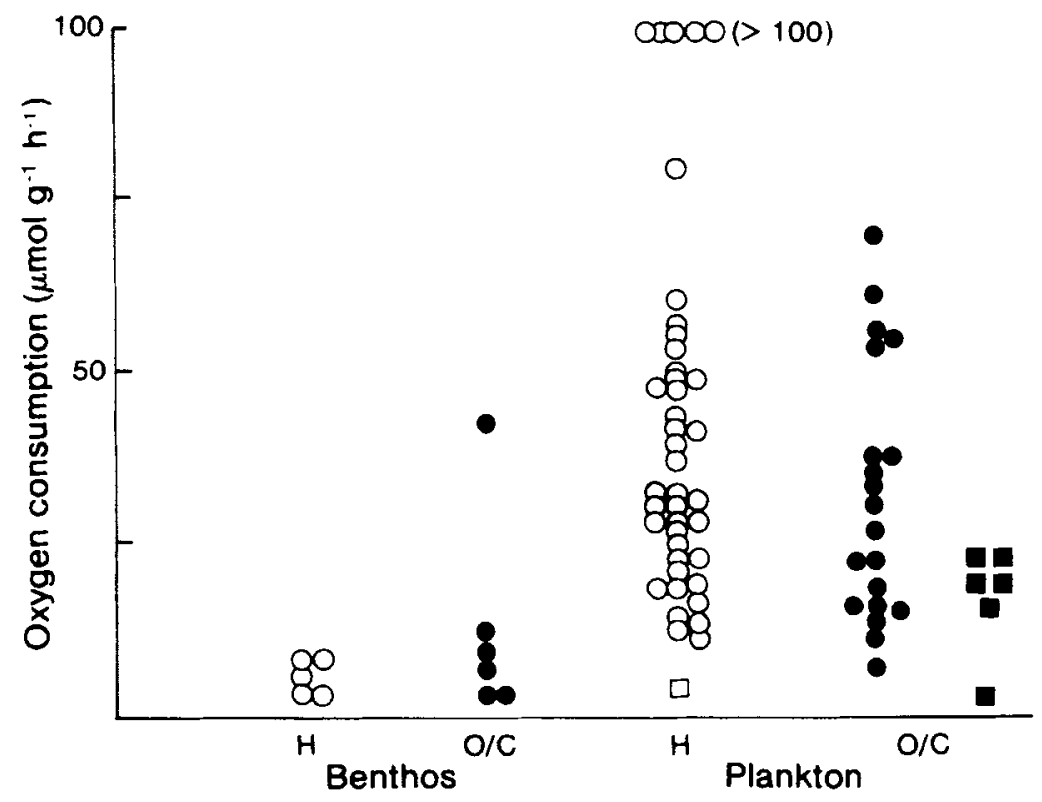

Fig. 5. Respiration rates of high latitude benthic and pelagic marine organisms. Oxygen consumption data are presented as $\mu \mathrm{mol} \cdot \mathrm{g}^{-1} \cdot \mathrm{h}^{-1}$ on a dry weight basis and have been recalculated from original data where necessary, using measured values for \% dry mass. Results for benthic species are from White (1975). Ralph \& Maxwcll (1977a b). Houlihan \& Allan (1982). Luxmoore (1984), and Peck ct al. (1986). and for pelagic organisms from lkeda (1970). Ikeda \& Hing Fay (1981), Ikeda \& Mitchell (1982). Hirche (1983. 1984), and Reinke (1987). Open symbols denote herbivores and closed symbols carnivores/omnivores. The data for gelatinous zooplankton are shown as squares. All data was obtained between $-1.5^{\circ} \mathrm{C}$ and $+1.5^{\circ} \mathrm{C}$. Modificd from an unpublished manuscript by Peck \& Clarke. 
account for differences of the order of that found here between plankton and benthos $(\times 6)$. There is also the difficulty that the basis of the tissue mass calculation differs between groups. In particular, values quoted for benthic herbivores (mainly molluscs) are in terms of dry flesh mass excluding shell, whereas those for other groups (especially pelagic species) are on the basis of total dry mass. Since any error included by ignoring skeletal material in some benthos will have reduced the observed difference between benthic and pelagic species, these variations in mathematical treatment will not have affected the overall conclusion.

\section{Overall energy flux}

The data in Figs. 4 and 5 indicate that the metabolic rates of planktonic species are significantly greater than those of benthic species (sometimes substantially so). Since food for both groups of organism is presumably reduced to much the same extent in winter, it is not surprising that pelagic species should require a greater overwintering reserve. The ability of planktonic carnivores to continue energy intake over winter explains the slightly smaller size of their lipid reserves (as discussed above). However, it is interesting that the reverse pattern appears to be found in benthic species (although the overall size of lipid stores in benthos are smaller than in plankton). The reason for this is unknown, but the explanation may be associated with locomotor activity; most benthic herbivores analysed so far have been sessile filter feeders whereas most carnivores/ omnivores were errant species.

It is notoriously difficult to estimate the total energy flux through a free-living marine organism. Most estimates for planktonic species are high, and for copepods in the production season some estimates have exceeded $100 \%$ body mass/day (see discussion in Cushing 1975). Euphausiids appear to consume about $20 \%$ body mass/day (Ross 1982; Stuart 1986; Clarke et al. 1988) and chaetognaths about 5-11\% (Øresland 1990). In contrast benthic invertebrate energy intake is usually of the order $1-5 \%$ (Clarke 1990). These data are sparse and have been obtained with a variety of techniques and approaches. Generally, however, they match the data for oxygen consumption in indicating a greater energy requirement for plankton than benthos.

What might explain this substantial difference in the energy requirements of benthic and planktonic existence? Since most measurements of oxygen consumption and total energy flux have been made during summer, the difference may reflect in part a greater rate of tissue synthesis in plankton compared with benthos (and the fast growth rates reported for some planktonic forms do not appear to be matched anywhere in the benthos). A more general explanation, in our view, is simply the cost of a planktonic existence. Although some indirect arguments have indicated a low cost to swimming activity in plankton (or strictly, a low incremental cost to vertical migration over the cost of staying at the same level in the water column) recent direct measures (Torres et al. 1982; Torres \& Childress 1983; Torres 1984) and theoretical analyses (Morris et al. 1983) have indicated that the energetic cost of swimming in planktonic crustaceans is high, especially at low speeds (Cowles et al. 1986).

This preliminary analysis would thus suggest that there are two basic ways of making a living in the sea. One is to live on the seabed where costs are low but food can be sought essentially in only two dimensions. The other is to move into the water column where energetic costs are higher, but so are the rewards since food can be sought in three dimensions. Few, if any, polar benthic species appear to grow fast. If the high summer growth rates of some zooplankton during the bloom are found to be a widespread phenomenon, this would emphasise further the differences in both the costs of and the benefits from a planktonic existence. However a more detailed examination of the data suggests an important third category, namely gelatinous zooplankton.

\section{The specialised energetic niche of gelatinous zooplankton}

In Figs. 4 and 5 data for gelatinous zooplankton have been plotted separately from non-gelatinous species. There are peculiar difficulties in dealing with data for gelatinous species, particularly in that precise measures of either dry mass or organic content are technically difficult. These difficulties may mean that expression of oxygen consumption data on a dry mass basis (as here) may not be entirely valid because of the high level of mineral ash and the possible inclusion of some residual water in the dry mass value. 
Nevertheless, the data we do have for polar gelatinous species, including both herbivores (salps) and carnivores (ctenophores, medusae, siphonophores) suggest that these groups have a quite distinct energetic strategy. They have a relatively low oxygen consumption, which is presumably because the achievement of near neutral buoyancy has reduced the metabolic costs of a pelagic existence. Direct measures of the cost of locomotion in gelatinous zooplankton have generally been low (Trueman et al. 1984; Larson 1987), although Daniel (1985) reported a high cost in small hydromedusae. Clearly, however, the costs of locomotion in gelatinous zooplankton cannot be high when oxygen uptake is low. Gelatinous zooplankton also show no marked tendency to store large amounts of lipid, and laboratory experiments have indicated a welldeveloped ability to degrow during periods of food shortage (see for example, Morris et al. 1983).

Many gelatinous zooplankton can grow and reproduce very fast when feeding conditions are suitable: salps, ctenophores, and medusae can all produce substantial populations rapidly. This indicates that peak energy throughput may be quite high. Although this would be reflected in an increased respiration rate, the low locomotor costs of gelatinous species mean that total respiratory costs would still be relatively low in comparison with, for example, crustacean zooplankton. Direct measures are badly needed.

Although, as we have emphasised, the data can only admit of a somewhat speculative interpretation we would propose that marine invertebrates can be classified broadly into three categories on energetic terms:

Benthic - Low locomotor costs, with small lipid stores; generally low energy throughput.

Non-gelatinous pelagic-High locomotor costs, with large lipid stores: high energy throughput.

Gelatinous pelagic - Low locomotor costs, with small lipid stores; variable energy throughput.

The inclusion of nektonic species such as squid and fish, many of which have achieved near neutral buoyancy through lipid stores or swimbladders, would have introduced a fourth category into this classification. It may be that gelatinous zooplankton have been able to combine the advantage of a lower oxygen consumption with at least some of the locomotory and dispersal mechanisms available to pelagic species. Their feeding strategies do not require significant burst activity and although they are fed upon by a variety of predators they have not developed energy-intensive modes of escape. They are nevertheless widespread in all seas of the world, and of enormous ecological importance (see, for example, Harbison et al. 1978). These striking differences between the energetics of gelatinous and non-gelatinous species clearly need further investigation.

Acknowledgements. - A.C. would like to thank C. C. E. Hopkins of the University of Tromsø for the opportunity to undertake comparative work in the Arctic, and for the invitation to participate in the Pro Mare Symposium. The British Antarctic Survey is a component body of the Natural Environment Research Council. We thank A. Atkinson for permission to use some of his unpublished data, and we thank the referees for helpful and perceptive criticism of an early draft of this paper.

\section{References}

Andrews, K, J. H. 1966: The distribution and life history of Calanoides aculus (Giesbrecht). 'Discovery' Rep. 34, 117162.

Atkinson, A. 1989: Distribution of six major copepod species around South Georgia in early summer. Polar Biol. 9, 353363.

Atkinson. A. 1991: Life cycles of Calanoides acutus, Calanus simillimus and Rhincalanus gigas (Copepoda: Calanoida) within the Scotia Sea. Marine Biol. 109. 79-91.

Baker. A. de C. 1959: Distribution and life history of Euphausia triacantha. Holt and Tattersall. 'Discovery' Rep. 29, 309-340.

Bàmstedt. U. 1976: Studies on the decp-water pelagic community of Korsfjorden, western Norway. Changes in the size and biochemical composition of Meganyctiphanes norvegica (Euphausiacca) in relation to its life-cycle. Sarsia 61, 15-30.

Båmstedt, U. 1980: Biochemical components as indicators of seasonal condition of deep-water zooplankton. Pp. 447-451 in Frecland. H. J. \& Levings, C. D. (eds.): Fjord Oceanography: Proceedings of the NATO Conference on Fjord Oceanography, Victoria, B.C., Canada, June 48, 1979. NATO Conference Series VI, Marine Sciences Vol. 4. Plenum Prcss, New York.

Bảmstedt. U. 1986: Chemical composition and energy content. Pp. 1-58 in Corner, E. D. S. \& O'Hara. S. C. M. (eds.): The biological chemistry of marine copepods. Clarendon Press. Oxford.

Carey. A. G. 1985: Marine Ice Fauna. Pp. 173-190 in Horner, R. A. (ed.): Sea Ice Biota. CRC Press. Boca Raton.

Childress. J. J. 1977: Physiological approaches to the biology of midwater organisms. Pp. 301-324 in Andersen, N. R. \& Zahuranec. B. J. (eds.): Oceanic sound scuttering prediction Plenum Press. New York

Chojnacki. J. \& Weglenska, T. 1984: Periodocity of composition. abundance, and vertical distribution of summer 2ooplankton (1977/78) in Ezcurra Inlct. Admiralty Bay (King George Island. South Shetland). J. Plankton Res. 6, 9771017 
Clarke, A. 1977: Seasonal variations in the total lipid content of Chorismus antarcticus (Pfeffer) (Crustacea: Decapoda) from South Georgia. J. Exp. Mar. Biol. Ecol. 27, 93-106.

Clarke, A. 1983: Life in cold water: the physiological ecology of polar marine ectotherms. Oceanogr. Mar. Biol. Ann. Rev. $21,341-453$.

Clarke, A. 1984a: The lipid content and composition of some Antarctic macrozooplankton. Bull. Br. Antarct. Surv. 63, 5770.

Clarke, A. 1984b: Lipid composition of two species of Serolis (Crustacea, Isopoda) from Antarctica. Bull. Br. Antarct. Surv. 64, 37-53.

Clarke, A. 1987a: The adaptation of aquatic animals to low temperatures. Pp. 315-338 in Grout, B. W. W. \& Morris, G. J. (eds.): The effects of low temperature on biological systems. Edward Arnold, London.

Clarke, A. 1987b: Temperature, latitude and reproductive effort. Mar. Ecol. Progr. Ser. 38, 89-99.

Clarke, A. 1988: Seasonality in the Antarctic marine environment. Comp. Biochem. Physiol. 90B, 461-473.

Clarke, A. 1990: Faecal egestion and ammonia excretion in the Antarctic limpet Nacella concinna (Strebel, 1908). J. Exp. Mar. Biol. Ecol. 138, 227-246.

Clarke, A. 1991: What is cold adaptation and how should we measure it? Am. Zool. 31. In press.

Clarke, A. \& Crame. J. A. 1989: The origin of the Southern Ocean marine fauna. Pp. 253-268 in Crame, J. A. (ed.): Origins and evolution of the Antarctic biota. Geological Society Special Publication No. 47, Geological Society, London.

Clarke, A. \& North, A. W. 1991: Is the growth of polar fish limited by temperature? In di Prisco, G., Maresca, B. \& Tota, B. (eds.) Biology of Antarctic Fishes. Proceedings of the Second International Conference, Ravello, Italy, 30 May1 June 1990. Springer Verlag, Berlin. In press.

Clarke, A., Quetin, L. B. \& Ross, R. M. 1988: Laboratory and field estimates of the rate of faecal pellet production by Antarctic krill, Euphausia superba. Mar. Biol. 98, 557563.

Clarke, A., Ellis-Evans, J. C., Sanders, M. W. \& Holmes, L. J. 1989: Patterns of energy storage in Pseudoboekella poppei (Crustacea, Copepoda) from two contrasting lakes on Signy Island, Antarctica. (Developments in Hydrobiology 49) Hydrobiologia 172, 183-191.

Cowles, D. L., Childress, J. J. \& Gluck, D. L. 1986: New method reveals unexpected relationship between velocity and drag in the bathypelagic mysid Gnathophausia ingens. DeepSea Res. 33, 865-880.

Cushing, D. H. 1975: Marine ecology and fisheries. Cambridge University Press. 278 pp.

Daly, K. L. \& Macaulay, M. C. 1988: Abundance and distribution of krill in the ice-edge zone of the Weddell Sea, austral spring 1983. Deep-Sea Res. 35, 21-41.

Daniel. T. S. 1985: Cost of locomotion: unsteady medusa swimming. J. Exp. Biol. 119, 149-164.

David, P. M. 1955: The distribution of Sagitta gazellae RitterZahoney. 'Discovery' Rep. 27, 235-278.

Ettershank. G. 1983: Age structure and cyclical annual size change in the Antarctic krill, Euphausia superba Dana. Polar Biol. 2, 189-193.

Falk-Petersen. S, 1981: Ecological investigations on the zooplankton community of Balsfjorden, northern Norway: seasonal changes in body weight and the main biochemical composition of Thysanoessa inermis (Krøyer), T. raschii (M. Sars) and Meganyctiphanes norvegica (M. Sars) in relation to environmental factors. J. Exp. Mar. Biol. Ecol. 49, 103-120.

Falk-Petersen, S., Sargent, J. R., Hopkins, C. C. E. \& Vaja, B. 1982: Ecological investigations on the zooplankton community of Balsfjorden, northern Norway: lipids in the euphausiids Thysanoessa raschii and $T$. inermis during spring. Mar. Biol. 68, 97-102.

Foxton, P. 1966: The distribution and life-history of Salpa thompsoni Foxton with observations on a related species, Salpa'gerlachei Foxton. 'Discovery' Rep. 34, 1-116.

Gatten, R. R., Sargent, J. R., Forsberg, T. E. V., O'Hara, S. C. M. \& Corner, E. D. S. 1980: On the nutrition and metabolism of zooplankton. XIV. Utilization of lipid by Calanus helgolandicus during maturation and reproduction. J. Mar. Biol. Ass. U.K. 60, 391-399.

Gliwicz, Z. M. 1990: Food thresholds and body size in cladocerans. Nature 343, 638-640.

Hagen, W. 1988: Zur Bedeutung der Lipide im antarktischen Zooplankton. Ber. Polarforsch. 49, 1-129.

Harbison, G. R., Maddin, L. P. \& Swanberg, N. R. 1978: On the natural history and distribution of oceanic ctenophores. Deep-Sea Res. 25, 233-256.

Hirche, H.-J. 1983: Excretion and respiration of the Antarctic krill Euphausia superba. Polar Biol. 1, 205-209.

Hirche, H.-J. 1984: Temperature and metabolism of planktonI. Respiration of Antarctic zooplankton at different temperatures with a comparison of Antarctic and Nordic krill. Comp. Biochem. Physiol. 77A, 367-368.

Hirche, H.-J. 1989: Egg production of the Arctic copepod Calanus glacialis: laboratory experiments. Mar. Biol. 103, 311-318.

Hirche, H.-J. 1990: Egg production of Calanus finmarchicus at low temperature. Mar. Biol. 106, 53-58.

Holm-Hansen, O., Mitchell, B. G., Hewes, C. D. \& Karl, D. M. 1989: Phytoplankton blooms in the vicinity of Palmer Station, Antarctica. Polar Biol. 10, 49-57.

Hopkins, C. C. E., Tande, K. S., Grønvik, S. \& Sargent, J. R. 1984: Ecological investigations of the zooplankton community of Balsfjorden, northern Norway: an analysis of growth and overwintering tactics in relation to niche and environment in Metridia longa (Lubbock), Calanus finmarchicus (Gunnerus). Thysanoessa inermis (Krøyer) and $T$. raschii (M. Sars). J. Exp. Mar. Biol. Ecol. 82, 77-99.

Houlihan, D. F. \& Allan, D. 1982: Oxygen consumption of some Antarctic and British gastropods: an evaluation of cold adaptation. Comp. Biochem. Physiol. 73A, 383-387.

Huntley, M. \& Escritor, F. 1991: Dynamics of Calanoides acutus (Copepoda: Calanoida) in Antarctic coastal waters. DeepSea Res. In press.

Ikeda, T. 1970: Relationship between respiration rate and body size in marine plankton animals as a function of the temperature of habitat. Bull. Fac. Fish., Hokkaido Univ, 21, 19112.

Ikeda, T. 1974: Nutritional ecology of marine zooplankton. Mem. Fac. Fish., Hokkaido Univ. 22, 1-97.

Ikeda, T. 1985: Metabolic rates of epipelagic marine zooplankton as a function of body mass and temperature. Mar. Biol. $85,1-11$.

Ikeda, T. \& Dixon, P. 1982: Body-shrinkage: a possible overwintering strategy of the Antarctic krill (Euphausia superba Dana). J. Exp. Mar. Biol. Ecol. 62, 143-157.

Ikeda, T. \& Hing Fay, E. 1981: Metabolic activity of zooplankton from the Antarctic ocean. Aust. J. Mar. Freshw. Res. 32, 921-930.

Ikeda, T. \& Mitchell, A. W. 1982: Oxygen uptake, ammonia excretion and phosphate excretion by krill and other Ant- 
arctic zooplankton in relation to their body size and chemical composition. Mar. Biol. 7I. 283-298.

Ivleva, I. V. 1980: The dependence of crustacean respiration on body mass and habitat temperature. Int. Rev. Ges. Hydrobiol. 65, 1-47.

Kane, J. E. 1966: The distribution of Parathemisto gaudichaudii (Guer), with observations on its life-history in the $0^{\circ}$ to $20^{\circ}$ sector of the Southern Ocean. 'Discovery' Rep. 34. 163198.

Larson. R. J. 1987: Costs of transport for the scyphomedusan Sromolophus meleagris L. Agassiz. Can. J. Zool. 65. 26902695

Larson, R. J.\& Harbison, G. R. 1989: Source and fate of lipids in polar gelatinous zooplankton. Arctic 42,339-346.

Lawrence, J. M. \& Guille. A. 1982: Organic composition of tropical, polar and temperate-water echinoderms. Comp. Biochem. Physiol. 72B, 283-298.

Lec, R. F. 1974: Lipid composition of the copepod Calanus hyperboreus from the Arctic ocean. Changes with depth and season. Mar. Biol. 26. 313-318.

Lee, R. F. 1975: Lipids of Arctic zooplankton. Comp. Biochem. Physiol. 51B, 263-266.

Lee, R. F. \& Hirota, J. 1973: Wax ester in tropical zooplankton and nekton and the geographical distribution of wax esters in marine copepods. Limnol. Oceanogr. 18. 227-239.

Littlepage, J. L. 1964: Seasonal variation in lipid content of two Antarctic marine Crustacea. Pp. 465-470 in Carrick, R., Holdgate, M. W. \& Prevost. J. (eds.): Biologie Antarctique. Actualités Scientifiques et Industrielles. 1312. Hermann. Paris

Littlepage, J. L. 1965: Oceanographic investigations in McMurdo Sound. Pp. 1-37 in Llano. G. A. (cd.): Biology of Antarctic Seas V. American Geophysical Union. Washington. D. C. Antarctic Research Series 5 .

Lonsdale, D. J. \& Levinton, J. S. 1986: Growth rate and reproductive differences in a widespread estuarine harpacticoid copepod (Scottolana canadensis). Mar. Biol. 91, 231-237.

Luxmoore, $R$. A. 1984: A comparison of the respiration rates of some Antarctic isopods with species from lower latitudes. Bull. Br. Antarct. Surv. 62, 53-65.

Marschall, H.-P. 1988: The overwintering strategy of Antarctic krill under the pack-ice of the Weddell Sea. Polar Biol. 9. 129-135.

Matthews. J. B. L. 1968: On the acclimatization of Calanus finmarchicus (Crustacea. Copepoda) to different temperature conditions in the north Atlantic. Sarsia 34, 371-382.

Morris, M. J., Gust. G. \& Torres. J. J. 1985: Propulsion efficiency and cost of transport for copepods: a hydromechanical model of crustacean swimming. Mar. Biol. 86 . 283-295

Morris. R. J. 1983: Absence of wax esters in pelagic Lake Baikal fauna. Lipids $18,149-150$

Morris. R. J. 1984: The endemic fauna of Lake Baikal: their general biochemistry and detailed lipid composition. Proc. $R$. Soc. Lond. B 222. 51-78.

Morris. R. J. McCartney. M. J. \& Schulze-Röbbecke, A 1983: Bolinopsis infundibulum (O. F. Müller): biochemical composition in relation to diet. J. Exp. Mar. Biol. Ecol. 67. 149-157.

Norrbin. F. \& Båmstcdt. U. 1984: Energy contents in benthic and planktonic invertebrates of Kosterfjorden. Sweden. A comparison of energetic strategies in marine organism groups. Ophelia 23, 47-64.

Oresland, V. 1990: Feeding and predation impact on the chac- tognath Eukrohnia hamata in Gerlache Strait, Antarctic Peninsula. Mar. Ecol. Progr. Ser. 63, 201-209.

Parkinson, C. L., Comiso, J. C., Zwally, H. J., Cavalieri, D. J., Gloersen. P. \& Campbell. W. J. 1987: Arctic sea ice 19731976: satellite passive-microwave observations. NASA SP489. NASA. Washington D.C. 296 pp

Peck, L. S., Morris, D. J., Clarke, A. \& Holmes, L. J. 1986: Oxygen consumption and nitrogen excretion in the Antarctic brachiopod Liothyrella uva (Jackson, 1912) under simulated winter conditions. J. Exp. Mar. Biol. Ecol. 104, 203-213.

Percy, J. A. 1979: Seasonal changes in organic composition and caloric content of an Arctic marine amphipod Onisimus (=Boeckosimus) affinis H. J. Hansen. J. Exp. Mar. Biol. Ecol. 40, 183-192.

Percy, J. A. \& Fife, F. J. 1981: The biochemical composition and encrgy content of Arctic marine macrozooplankton. Arciic 34, 307-313.

Priddle, J., Hawes, I. \& Ellis-Evans, J. C. 1986: Antarctic aquatic ecosystems as habitats for phytoplankton. Biol Rev. 61, $199-238$

Ralph, R. \& Maxwell, J. H. G. 1977a: The oxygen consumption of the Antarctic limpet Nacella (Patinigera) concinna. Bull. Br. Antarct. Surv. 45, 19-23.

Ralph, R. \& Maxwell, J. G. 1977b: The oxygen consumption of the Antarctic Lamellibranch Gaimardia trapesina trapesina in relation to cold adaptation in polar invertebrates. $\mathrm{Bull}$. $\mathrm{Br}$. Antarct. Surv, 45, 41-46.

Reinke, M. 1987: Zur Nahrungs- und Bewegungsphysiologie von Salpa thompsoni und Salpa fusiformis. Ber. Polarforsch. $36,1-89$

Ross, R. M. 1982: Energetics of Euphausia pacifica. I. Effects of body carbon and nitrogen and temperature on measured and predicted production. Mar. Biol. 62, 131-137

Ross. R. M.. Quetin. L. B. \& Kirsch, E. 1988; Effect of temperature on development times and survival of early larval stages of Euphausia superba Dana. J. Exp. Mar. Biol. Ecol. 121. 55-71.

Sargent, J. R. \& Falk-Petersen. S. 1981: Ecological investigations on the zooplankton community of Balsfjorden. northern Norway: Lipids and fatty acids in Meganyctiphanes norvegica, Thysanoessa raschii and Thysanoessa inermis during midwinter. Mar. Biol. 62, 131-137.

Siegel, V, 1987: Age and growth of Antarctic Euphausiacea (Crustacea) under natural conditions. Mar. Biol. 96, 483 495.

Smetacek, V., Scharek, R. \& Nöthig, E.-M. 1990: Seasonal and regional variation in the pelagial and its relationship to the life history cycle of krill. Pp. 103-114 in Kerry, K. R. \& Hempel, G. (eds.): Antarctic Ecosystems. Ecological Change and Conservation. Springer Verlag. Berlin.

Stuart. V. 1986: Feeding and metabolism of Euphausia lucens (Euphausiacea) in the Southern Benguela Current. Mar. Ecol. Progr. Ser. 30, 117-125.

Sullivan, C. W. McClain, C. R., Comiso, J. C. \& Smith, W O. 1988: Phytoplankton standing crops within an Antarctic ice edge assessed by satellite remote sensing. J. Geophys. Res. 93 C10.12487-12498.

Tande, K. . Hassel, A. \& Slagstad, D. 1985: Gonad maturation and possible life-cycle strategies in Calanus finmarchicus and Calanus glacialis in the northern Barents Sea. Pp. 141-155 in Gray, J. S. \& Christiansen, M. W. (eds.): Marine biology of polar regions and effects of stress on marine organisms. $\mathrm{J}$ Wiley and Sons. Chichester.

Torres. J. J. 1984: Relationship of oxygen consumption to swimming speed in Euphausia pacifica. II. Drag. efficiency 
and a comparison with other swimming organisms. Mar. Biol. 78, 231-237.

Torres, J. J. \& Childress, J. J. 1983: Relationship of oxygen consumption to swimming speed in Euphausia pacifica. I. Effects of temperature and pressure. Mar. Biol. 74. 79-86.

Torres, J. J., Childress, J. J. \& Quetin, L. B. 1982: A pressure vessel for the simultaneous determination of oxygen consumption and swimming speed in zooplankton. Deep-Sea Res. 29. 631-639.

Trueman, E. R. Bone, Q. \& Bracconot, J. C. 1984: Oxygen consumption in swimming salps (Tunicata: Thaliacea). $J$. Exp. Biol. 110. 323-327.

Voronina, N. M., Vladimirskaya, Ye. V.\& Zmiyevskaya, M. I. 1978: Seasonal variations in the age composition and vertical distribution of common zooplankton species in the Southern Ocean. Oceanology, Wash. (English transl.) 18, 335-338.

Voronina, N. M. , Menshutkin, V. V. \& Tseytlin, V. B. 1980: Production of the common species of Antarctic copepod,
Calanoides acutus. Oceanology, Wash. (English transl.) 20. 90-93.

Wacasey, J. W. \& Atkinson, E. G. 1987: Energy values of marine benthic invertebrates from the Canadian Arctic. Mar. Ecol. Progr. Ser. 39, 243-250.

Ward, P. 1984: Aspects of the biology of Antarctomysis maxima (Crustacea: Mysidacea). Polar Biol. 3, 85-92.

White, M. G. 1975: Oxygen consumption and nitrogen excretion by the giant Antarctic isopod Glyptonotus antarcticus Eights in relation to cold adapted metabolism in marine polar poikilotherms. Pp. 707-724 in Barnes, H. (ed.): Proc. 9th Europ. Mar. Biol. Symp. Aberdeen University Press.

Zwally, H. J., Comiso, J. C., Parkinson, C. L., Campbell, W. J., Carsey, F. P. \& Gloersen, P. 1983: Antarctic sea ice, 19731976: satellite passive-microwave observations. NASA SP459. NASA, Washington, D.C. 206 pp. 
